\title{
Reading and Writing Instructions in the Foundation Phase Classrooms
}

Doi:10.5901/mjss.2014.v5n10p363

\author{
${ }^{1}$ Masello Hellen Phajane \\ 2 Lenyai Ellen Moipone \\ ${ }^{1}$ Department of Early Childhood Education (ECE) \\ Email: phajamh@unisa.ac.za \\ 2Department of Early Childhood Education (ECE) \\ University of South Africa (UNISA), PO Box 392 Pretoria 0003 \\ Email: lenyaem@unisa.ac.za
}

\begin{abstract}
It is no news that reading problems plague our country South Africa; the media have informed us of this over and over again, recent reports on the high matric failure rate show that most children still cannot read and write and this tends to drag down the overall matric performance (Department of Basic Education 2010:30) (DBE). Little, if any, has examined teacher's perspectives on the methods used for reading instruction at primary schools in these grades. This study is qualitative in nature and examined first grade teachers' perspectives on teaching beginning reading in Setswana using different approaches: the traditional method, sentence method, Breakthrough to Setswana programme and Curriculum and Assessment Policy Statement (CAPS) approach. Data for this paper was collected from 4 different foundation phase schools in Brits District of North West Province in South Africa. The findings suggest that teachers felt differently about the different approaches of teaching beginning reading. Finally, teachers should also be supported by the Department of Basic Education in conducting investigation on teaching and learning in their classrooms.
\end{abstract}

Keywords: Sentence, Breakthrough, Reading, teachers, children, schools, methods.

\section{Introduction}

The International Reading Association (2005:2) (IRA) stated: "every child deserves excellent reading teachers, because teachers make a difference in children's reading achievement and motivation to read." The focus here is on the power of the teacher, not the power of a programme used by a teacher. Programmes can help or hinder a teacher's instruction, but exemplary teachers know how to tailor the available programs to the unique strengths and needs of their children. Exemplary teachers realise how important each minute of each day is, in helping children learn to read and write. They also reflect on their practice, and learn from mistakes, Gordon \& Browne (2004:32). Teachers naturally are an important part of a school resource Marshall, (2002:47), faced with the challenge of engaging children in language learning developing literacy skills and creating conducive environments for learning Macdonald, (2002:3). They are the ones who deal with learning on a day to day basis in particular contexts for this reason, their perspective on teaching beginning reading are critical. Most importantly, they are the key role players who transmit all aspects of curriculum innovations to children. Close interaction with teachers will give policy makers, curriculum implementers and education officials some idea of the extent to which methods of teaching beginning reading has made its way to beginners.

\section{Research Methodology}

This research is positioned as a qualitative case study, and according to De Vos, Delport; Fouche and Strydom (2006:34), it meets the interpretive researcher's purpose of understanding situations that are complex. This research is based on the information collected at schools that are complex networks in which staff members interact at various levels. Levin \& Rock (2003:43) are of the opinion that interpretive social research emphasises the complexity of human beings, and attempts to construct and understand their worlds. As mentioned before, the researchers of this paper collected data from 8 foundation phase schools in Bojanala District at Brits. Four teachers were observed and were later interviewed on the teaching of beginning reading. In order to establish how the research was approached, observations and interviews were used to collect many views. For the purpose of this paper, four teacher case studies from four different schools will be reviewed. 


\section{Research Findings}

Before the research questions were asked, an overview of teacher' names, professional qualifications, gender, teaching experience, age and their home language were discussed.

\section{Qualifications, the Profile and the Demographics of the Research Participants}

\subsection{Professional Qualifications}

Teacher 1 is professionally qualified, and has a Basic Education Teacher Diploma (BETD) and an Advanced Certificate in Education (ACE) reassured her to be very good with teaching reading. Teacher 2 her professional qualifications are Primary Teachers Certificate (PTC), Further Diploma in Education (FDE). Teacher 2 with a qualification of Primary Teachers Certificate (PTC) this may sound outdated, and may also lack content knowledge about language teaching, since she trained when entrance requirements were only Grade 8 which was Form 3 by then. This could impact negatively on her teaching and learning of reading in home language and that could live her tied to old methods that might not produce good results. But, she upgraded herself and obtained Further Diploma in Education (FDE) that kept her updated.

Teacher 3 her teaching qualifications are National Professional Diploma in Education (NPDE), Advanced Certificate in Education (Inclusive Education) (ACE) that also sounded impressive. Teacher 4 is also professionally qualified and has a Diploma in Development Studies (DDS), as well as Bachelor of Arts General Degree (BA). Teacher 4 who may not be as well qualified, with Diploma in Development Studies (DDS) had also a Bachelor's degree (BA) could be the only one to experience teaching problems as her qualifications lack professional teaching method.

All the teachers had recognized teaching qualifications being teaching diplomas which qualified them as professionals. They are all qualified professional teachers they are all competent to teach Grade 1 level. Given such qualifications of teachers in the research, assured that all the teachers are not expected to be barriers to teaching reading. It is evident that teacher qualifications could not be regarded as a reason for lack of knowledge to teach reading.

\subsection{Gender}

All teachers were females and usually at primary schools they are called mothers; they have more knowledge of dealing with young children since they are parents themselves. Female teachers are known to be passionate motherly, considerate towards children in general, children also feel safe around them and such learning environment could be more relaxed and conducive to learning. These female teachers were all responsible for Grade 1, and were also taught how to teach reading in the Home Language $(\mathrm{HL})$. However, the observed poor reading skills do not confirm this. There is no reason to blame children's reading skills on poor teachers qualifications because they were all qualified. There might be another reason why children cannot read in Setswana.

\subsection{Teacher's ages}

Teacher 1 is a 52years old Grade 1 female teacher at School A. Teacher 2 also a Grade 1 female teacher of 50 years of age, at School B. Teacher 3 is a 47 years old female teacher and has been employed in a Grade 1 at School C. Lastly, Teacher 4 was also one of the Grade1 female teachers at School D and has 45 years of age. Their ages range from 45, 47 , and 50 to 52 years of age,

\subsection{Teachers' teaching experiences}

In general, all the teachers were also mature in age, their teaching experiences ranged from 18, 23, 27, to 30 years. Teacher 1 with the necessary qualifications, an experience of 30 years seemed to be the longest in service, with a good track record of experience. Teacher 2 with confidence, dedication and self given is also a good teacher. Teacher 3 who is also more knowledgeable and experienced with children's problem identification, all these proved that they are all well experienced teachers.

Although Teacher 4 is the least in teaching experience of all, 18 years still represent good experience because she is not a beginner. They all had a good reputation for teaching Grade 1's at their respective schools. None of the teachers can be regarded as inactive or unproductive. All these teachers were very good; they were interested in their work and also productive and could be trusted with teaching reading to children effectively. 


\subsection{Teacher's home language}

The home language of children in the research is Setswana; Teacher 1, 3 and 4 were Setswana home speakers, except for Teacher 2 who is a Northern Sotho speaker (Sepedi). Although Teacher 2 is Northern Sotho speaking, this does not create a problem because Northern Sotho is close to Setswana and she is fluent in Setswana, again every language uses reading uses methods to teach reading to beginners.

\section{The Organization Of Schools}

School A, although it had a low enrolment of 35 children, it was congested because of the small class size. Children were seated in twos and threes on desks of tightly packed rows. The desks were not easily movable since the desk tops and the seats were connected, no flexibility children were uncomfortable with low concentration. As a result Teacher 1 struggled to group them according to their abilities, so that she can be able to see those who are slow and keep a strong eye on them. If they are bundled together, it is not easy; it may take a longer time to identify them. Visual reminders (charts) were displayed in the classroom.

School B, the classroom was not decorated with pictures and charts on the wall, there were boxes of children's reading books that were also shared amongst children. Without display of reading pictures and an exposure to large amount of print in books, children are unlikely to develop automaticity and become fluent readers Cunning and Stanovich, Murray (2006:51-59), also claims that children must be given adequate exposure to print in Grade 1.

School C, was relatively new with modern buildings; the classrooms were kept tidy and also clean. Because of the conducive classroom environment, Teacher 3 got sufficient time to work with all the children. The school served the poor, largely illiterate and isolated communities. In comparison with the other research schools A and B, this school was more functional with teachers regularly in their classes and children moving from class to class between periods quickly.

School D, has five rooms, four classrooms and a room for meetings, while other classes were held under trees and in makeshift shacks. A combination of Grade 1 and 2, Grade 3 and 4, and a Grade 5 and 6, which according to Miller (2002:32) is called a multi-grade classroom. In a combined classroom of Grade 1 and 2, 120 children were crammed into one classroom that was designed for 35 children. Children from Grade 1 and 2 shared the same classroom, which was also used as the teacher's staffroom, administration office and storeroom. In these classrooms the difficult grades are taught alternatively i.e. Grade 5 first period and Grade 6 second period, one grade sits outside and waits patiently for the other to finish its lesson. It was difficult for children to focus on their teacher, especially when other grades are having free periods; this was an unreasonable task for the teacher.

Generally children in all schools (classrooms) were arranged or seated in church style facing one direction. From the classroom observation children did not work cooperatively together, the teacher gave the same tasks for all the children whereby each learner work out his or her activity (individual activity). In this case, teachers should encourage children to work together and create a flexible learning environment, by giving different tasks as children are not learning at the same pace.

\section{What Was Observed}

Below are the detailed descriptive narratives of what was observed, from the research observations. They are described per participating school and teacher. The observations focused on five things namely; methods used in the teaching of reading of children; teacher learner interaction; lesson activities or methods; the classroom size, availability of resources, the following are the results:

\section{Focus-Group Interview With Grade 1 Teachers}

\subsection{Researcher: What method/s do you use to teach beginning reading in mother tongue (Setswana)?}

Teachers: we use different types of methods. We use multi-level teaching because children vary according to their level of ability. We use methods and approaches such as traditional, sentence, CAPS, Breakthrough to Setswana, we also use storytelling, whereby the teacher tells a story, using pictures and a big book for that matter, and we also allow the children to retell the story and also dramatise it, some children learn best through songs, others like rhymes, and others can understand and cope by listening while the teacher is teaching. Some can even formulate a game from an activity, children grasp a lot as they play, it is learning through play, and they smile and make eye contact with each other. 
The researchers' point of view, teachers responded very positively regarding the combined methods of teaching reading to beginners. One teacher said; "I got lots of ideas to present reading in an interesting way". Another teacher appreciates the integrated reading methods. Most of the teachers indicated that they experienced frustrations during teaching beginning reading to beginners, they recommended more workshops on approaches and methods of teaching beginning reading to first grade children.

\subsection{Researcher: Why have you chosen to use this method/s to teach beginning reading, do you have reasons for that?}

Teachers: we liked these methods very much and we saw the difference they made to the children, we are comfortable using them as long as we are adjusting them to our need and style. Children needed to be taught sounds before they could read books, once the child has mastered word formation; she or he never has difficulty.

They said; "we did not choose this method of curriculum (CAPS), we only receive a word from the top (National level), served on a tray (policies)". They just say, right, now there is a curriculum change, we are implementing it now! But we don't know how it comes about no! no! we don't know. We are controlled from the top to the central government. Sometimes inspectors and subject specialists do not agree with the changes, if you try to speak out to them that this approach does not work well for children, they would say, 'it works in other schools, and if you cannot do it, leave by the door', so you better be careful because that is their preferred way of silencing teachers who raised questions, by asking them to leave through the gate or expelled. There is no flexibility, we can do things that we think can work well and fast for us and our children, but we cannot do it freely, we can't. We can try our ways of doing things, but the subject advisors do not have to know about them.

\subsection{Researcher: Do you experience problems when you teach reading? If yes, what type of problems do you experience?}

Teachers: the problem is we haven't done training in any method, it was not even offered at the college of education during our training years. You can only do it on your own, perhaps on part time basis. At times we mix things (old and new methods) and use other approaches. When we are in class, we use our own way that we think will propel children forward, we try hard to expand children's minds in ways that we can. There is nothing wrong with all the methods even when most teachers criticize them; they are dynamic, too dynamic. It is just that we need proper training, loudly and emphatically. For that reason, teachers would need to be provided opportunities to systematically document their own ways of teaching, as they referred to it. In that way, the methods and programs will be enriched and will gain vitality rather than the sterility that comes out of routine.

From the researcher's observations, all the teachers indicated that even though they were dedicated to their work, there are some problems and challenges that they came across. For instance they complained that they were overloaded with work in their classrooms, and sometimes children needed more attention on specific activities (reading). They also indicated that they need a remedial teacher in the grade 1 classrooms to assist them with those children who experienced barriers, especially in home language (Setswana). They noted that most of the children experienced barriers in reading and spelling Setswana and felt that the remedial teacher would assist them to address that subject matter.

\subsection{Researcher: Are your children able to read?}

Teachers: only when they had demonstrated that they could read and write some words and sentences correctly and independently, we also believed that children should not be exposed to books until they were ready to read a lot of words and sentences, (bored facial expressions).

From the researcher's point of view, the focus group interview, as well as the observations made in Grade 1 classrooms revealed that the teachers used different methods to teach beginning reading Setswana to beginners and also to accommodate every child's learning needs and level of ability. The data that was analysed also revealed that the teachers used different lesson plans and activities to include all the children in teaching and learning.

\subsection{Researcher: What resources do you use?}

Teachers: when teaching reading we use pictures, puppets and other relevant resources to arouse the children' interest; we use shared reading, whereby we use a big book which has got visible pictures with limited text; we use pictures and real objects. Whenever we teach, we use relevant teaching aids. We make sure that the teaching aids or resources are 
attractive and visible enough. Teacher 3: not to say that I'm speaking for my school, but you can see that our classrooms are conducive to teaching and learning to read. They are bright, attractive and full of visible teaching aids or resources on the walls. The resources are also used for incidental reading for the children and walls. The teaching aids are also used for incidental reading for the children and most importantly to attract their interest and to accommodate each individual in reading. We improvise in many ways to make resources that are relevant and attractive to arouse the children's interest in reading. We make sure that the resources are learner-friendly and that every child can use them, (they nod).

Researcher: End of the interview. Thank you so much.

\section{Discussions on Observed Classrooms}

Although, the teachers sincerely believed that their efforts in the classroom were yielding fruitful results, the reading methods that many adopted are not conducive to developing skilled readers. Both Macdonald (2002:58) and Labuschagne (2001:60) reported that there is a tendency for children in disadvantaged black schools to become "soundcentred readers", where the pedagogic focus is on getting readers to decode printed information with little attention paid to meaning. As a result the children end up "barking at print", often in quite a competent manner, leaving the teacher satisfied that the children can indeed "read". This was clearly reflected in the learner's performance on the Setswana word recognition tasks where the children could decode high frequency words in isolation, but performance dropped dramatically when they had to read a short story, and their comprehension was poor.

Responses to one of the open-ended questions asking teachers to explain how they dealt with reading in their classroom situation provided an interesting window onto some of the reading methods adopted in the classroom. For example, all the teachers mentioned the use of charts, these are charts of consonants and vowels combinations that are commonly used to teach the various sound sequences in the African languages; e.g. sa, se, si, so, su, and flash cards as a way of practicing reading, while Teacher 1 and 2 said they made the children read words and sentences together in chorus in groups.

Furthermore, all the teachers said they made a point of identifying difficult words in a text, writing them on the board and making the children practice reading them from the board. Many of these activities involve attention to print list of letters or words rather than to the reading of more extended discourse, such as short stories. Although a sound phonics basis is important for reading especially in the early year, Hugo (2010:11), attention to decoding at the expense of comprehension is not beneficial in the long run. Children need to be exposed to extended discourse in the form of short narrative or descriptive tests in order to practice bringing both decoding and comprehension process to bear on making from the text, Hugo (2010:11).

Teacher 4 recently communicated to the researcher about her unhappiness when an official (subject specialist) told her that such charts were not part of the CAPS syllabus and should not be used. Teacher 3 commended on the programme's instructional approach (traditional) that she appreciated the fact that the programme is child-centred. The programme considers the child's experiences and builds upon them. This makes learning to be more meaningful for the culturally disadvantaged child. The various activities in the programme also make an attempt to involve the child activity in learning.

Teacher 4 stated that she liked the mixed methods strategy because it stressed presentation, practice and above all mastery. "In the teaching of letter sounds, if a child makes a mistake you don't punish him but you go back to the beginning and teach again because he may not have understood well at the beginning stages". Letter-sound instruction is perceived as a useful aspect of the designed programme as, in the opinion of the teachers, it provides basis for letter and word recognition and decoding, Kamii \& Manning (2005:38-46). Learning letter sounds is also an enjoyable experience with pleasurable results for children, "because even when they are outside the classroom, one finds them applying the skill identifying and naming known letters in adverts and other places".

The strategy for teaching letter sounds which is adopted from International Reading Association (IRA) (2002:30-46) and used in the programme seems to meet with approval from the teachers. From the teachers views it seemed justified to conclude that teachers accept the principle of letter-sound teaching and the direct teaching of letter sounds putting emphasis on mastery. Teaching letter sounds is therefore, on the basis of the respondents' views above, favourably considered to be an essential part of a reading readiness programme. According to survey research, Lessing \& De Witt (2002:286) teachers currently teaching reading in a grade one class indicated a need for further training in teaching reading.

Teachers described their teaching reading success as follows: "teaching reading to school beginners is not difficult but it takes hard work, commitment and dedication on the part of the teacher, the learner and the parent. Once this partnership is established at the beginning of the year, and then only success will follow." This has been challenged in 
recent times in light of South Africa's literacy results being among the worst in Africa (Browne 2007:48). The following discussions presented the descriptions and critiques of each of these methods:

\section{Similarities}

Despite the approaches used by the teachers in the study, they did encounter many challenges. This was the case in the entire classroom situation. Some of the challenges included: Some children did not understand the Setswana language, making reading difficult. They come from preschools that have done very little or no school readiness with the children. Some parents lack the time or do not make an effort to assist their children with reading. Some parents do not understand the written language themselves, so they cannot help their children to read.

Story telling: this study reveals that all four teachers used the story telling technique that featured prominently in the entire lessons very well. The teachers' love for oral stories could be attributed to the fact that when teachers teach reading in a Setswana context, they draw on their culture. Teacher's Guide, (2003:9) argues that stories provide a context for developing language, which is a pre-requisite for learning to read. Stories are also supported by the curriculum for Grade 1 by emphasizing that the children's imagination and desire to hear stories should be promoted Department of Education (2002:5) (DoE).

Visual materials used to support reading: Every lesson that the researcher observed used pictures or posters among the teaching aids the teachers had prepared. This technique was used to good effect by all the four teachers in their lessons. They have been looking at the picture, now they are telling a story about the picture. All the teachers put the pictures, posters, magnetic alphabets on the chalkboard and identified words for children to read, this is a clear indication that the four teachers attached great value to visual materials.

None of the teachers teach reading using books: This was a common element that featured across the four teachers' lessons, the fact that some of the children have an experience of books from home and pre-school needs to be well observed by teachers. However, there was not a single lesson where children practised reading from a book. They depended almost entirely on the chalkboard, flashcards and the charts.

Reading Context: This research revealed that the four teachers did not have a deep understanding of the concept 'literacy', and therefore worked on a narrow understanding of literacy themselves. This came out strongly in the manner they taught reading, because they only targeted reading words with the children, and the words they read, though they came from the stories, were detached from their contexts because they were treated separately from the stories. In other words, children only understood the words, and not the contexts in which they were used in their stories.

School Readiness Program: Schools (A \& B) used Reading Readiness Program for assessing the progress of the children, they used formal texts, such as distinguishing colors, matching and transcribing words in flash cards etc. They used these activities as part of determining children who were ready for formal instruction and reading.

Inseparability of reading and writing: There were instances throughout all the teacher's lessons where the skills of reading and writing were seen to be totally linked and inseparable. This was demonstrated by the fact that every time a word was read, the teacher again wanted the children to write it on the chalkboard, in their workbooks on air as demonstration of having known how to read it. They all maintained the inseparability of reading and writing and confirmed and used it.

No clear distinction between methods and techniques: One interesting dimension that the researcher noticed both in the interviews and in the lesson observations across the four teachers is that they seem not to have a clear distinction between methods and techniques. They could not establish the difference between the two, and they kept using them interchangeably. Some of the examples that show the teachers' lack of understanding of the two concepts could be seen as follows: All the teachers said that when they begin with their reading lesson, it should start with a story. They spoke as if the story was a teaching method and not a technique.

\section{Differences}

Despite the existence of similarities among the research participants, the researcher realized there were differences as well. The researcher saw it valuable to have teachers using different approaches because it provided a wider perspective on how teachers under varying contexts were teaching and how their perspectives were informed by different approaches though these were minimal, for example:

Different use of teaching methods and approaches: the four teachers used the following different methods and programme to teach beginning reading to beginners, Breakthrough to Setswana programme, School Readiness programme, Sentence Method, Traditional Method, lastly the Outcomes Based Education Approach. 
Confusing syllables with words: while the third and the fourth teachers referred to the syllables, ba, be, bi, bo, bu, as being words, Teacher 1 and Teacher 2 labeled them properly as syllables.

Lack of curriculum knowledge: only one out of the four teachers had no sense of what the outcomes of the lesson she was presenting might be. The last teacher was not able to make connection between this outcome and what she should be looking for when assessing the performance of her children. When the researcher asked the teacher what she saw as the outcome of the lesson she struggled to tell her.

The absence of shared or Buddy reading: only the teacher at School D emphasized that reading is the vital part of both grades ( 1 and 2 ) daily program. Buddy reading was implemented by allowing at least three children to share a book but, the three teachers neglected the element of shared reading with the children. Caldwell (2002:45) defines shared reading as reading that is done by the teacher or parents with a learner from a book. With parents it is a one-to one interaction, but a teacher may read with a group of children sitting around them.

Only one of the four teachers did this, and as indicated in the section above, they stuck to words, either on the chalkboard, flashcards, or on the charts. The researcher feels it was a missed opportunity by the teachers she interviewed. This study was conducted at the beginning of the year, the time teachers are expected to do shared reading with the children, according to Caldwell (2002:47), shared reading is a practice that is carried out by teachers in early years' classrooms. There could be various reasons why the three teachers did not consider shared reading in their classrooms.

The problem of language: A further language problem was encountered in the interviewing process. Interviews with one teacher were carried out in Sepedi or Northern Sotho. Many of the concepts associated with the teaching of reading, for example, 'method' and 'technique' originate in English. There are no exact translations into Setswana or Sepedi, which has a single word for these two concepts. When the researcher asked them about the methods they use to teach reading, this is what they had to say: it should be started with a story, we always tell them a story, which goes together with the reading, after that story, and then they have to read the vocabulary words.

\section{Conclusion}

However, it is clear from the discussion that the programmes as implemented by the Provincial Education Department are failing to upgrade current teachers to fit into the new foundation phase syllabus that follows the CAPS method of teaching reading. The teaching reading methods conducted by the Brits District officials, subject specialists and coordinators indicated that they had failed to address the needs of the teachers and children especially those of foundation phase. These methods of approach have impacted a great deal on the current teaching of reading.

\section{References}

Browne, A. (2007). Teaching and Learning Communication, Language and Literacy. London: Paul Chapman. Caldwell, J.S. (2002). Reading Assessment. A primer for teachers and tutors. London: TheGuilford Press.

Cunningham, P., Stanovich, D. \& Murray, S. (2006). What if they can say the words but don't know what they mean? The Reading Teacher, 59(3):708-711.

Department of Basic Education (DBE), (2010). Curriculum and Assessment Policy Statement (CAPS). Pretoria: DBE.

Department of Education. (2002). Revised National Curriculum Statement Grades R-9; Overview and Languages (English), Home and First Additional Language Gazette No.23406, Vol.443, May, 2002. Pretoria: Government Printer.

De Vos, AS. Strydom, H. CB \& Delport, CSL (Eds.) (2006). Research at grassroots. Pretoria: Van Schaick.

Gordon, A. M., \& Browne, K.W. (2004). Beginnings \& beyond. Foundations in early childhood education (6th Ed.): Thompson Delmar Learning.

Hugo, A.J. 2010. Foundation phase teachers: The "battle" to teach reading Journal for language teaching 44/2 Unisa Pretoria.

International Reading Association. (IRA) (2002). Leaders testify before reading panel. Reading Today, 16(1):1-6.

International Reading Association. (IRA) (2005). What is evidence-based reading instruction? A position statement of the International Reading Association. Newark, D.E: Author.

Kamii, C., \& Manning, M. (2005). Phonemic awareness and beginning reading and writing. Journal of Research in Childhood Education, 17(1):846.

Kuhn, M. R., \& Stahl, S. A. (2003). Fluency: A review of developmental and remedial practices. Journal of Education Psychology, 95(1):3-21.

Labuschagne, S. (2002). Family literacy project, evaluation report. Unpublished research report: Durban.

Lessing, AC \& De Witt, MW. (2002). Teaching reading in an OBE framework. Journal for Language Teaching, 36(3):274-288.

Levin, B.B., \& Rock, T.C. (2003). The effect of collaborative action research on pre-service and experienced educator partners in professional development schools: Journal of Educator's professional development. Department of Education and training: Australia.

Macdonald, C.A. (2002). Zebediela District Baseline study for the Molteno project. Unpublished research report, Johannesburg: Zenex foundation. Marshall, S.C. (2002). Are they really reading? Expanding SSR in the middle grades. Portland, ME: Stenhouse.

Miller, D. (2002). Reading with meaning teaching: Teaching comprehension in the primary grades. Portland, ME: Stenhouse. 